\title{
Evaluation of Learning Programs at Elementary School Level of "Sekolah Alam Indonesia (SAI)". (Evaluative Research Using Countenance Stake's Model)
}

\author{
Rina Harjanti", Yetty Supriyati, Wardani Rahayu \\ Research and Evaluation of Education, State University of Jakarta, Indonesia \\ *Corresponding author: tu.pps@unj.ac.id, rinaharjanti@gmail.com \\ Received December 01, 2018; Revised January 04, 2019; Accepted February 06, 2019
}

\begin{abstract}
The purpose of this study was to evaluate learning programs at the primary school level of SAI using countenance Stake's evaluation model. Data is obtained through the results of observations, interviews, and documentation with several stakeholders. The results revealed that: in congrruency, evaluation at the stage of antecedents obtained a percentage of $76 \%$ which means that education planning at SAI in the category is in accordance with the applicable education planning standards, at the stage of transactions it gets a percentage of $93 \%$, which means that the process of implementing learning at SAI has been very in accordance with the standards of the learning process in the Minister of Education and Culture Regulation No. 22 of 2016, and at the stages of outcomes, it still must be a concern of the school especially in preparation for facing USBN. In contingency, the learning program in the "School of Nature Indonesia" in the category is in accordance with the learning standards in the national curriculum starting from planning, implementation, and school evaluation.
\end{abstract}

Keywords: countenance stake's evaluation model, learning program, 'SAI'

Cite This Article: Rina Harjanti, Yetty Supriyati, and Wardani Rahayu, "Evaluation of Learning Programs at Elementary School Level of "Sekolah Alam Indonesia (SAI)". (Evaluative Research Using Countenance Stake's Model)." American Journal of Educational Research, vol. 7, no. 2 (2019): 125-132. doi: 10.12691/education-7-2-2.

\section{Introduction}

Education in Indonesia has been considered quite good in developing better quality human resources since Indonesia's independence. This is based on the decline in unemployment in Indonesia that occurs every year. However, when compared to other countries such as ASEAN countries, education in Indonesia is still far behind neighboring countries such as Malaysia and Singapore. According to statistics from the Human Development Indices and Indicators in 2018, the position of education in Indonesia is still ranked 116th in the world in the category of medium human development. The percentage of students who drop out of school at the elementary level in Indonesia is $18.1 \%$ of the total number of registrants [1]. Increasing student enrollment rates will not have a positive impact on national economic growth if students do not get the adequate quality of learning. The high cost of education is inseparable from the availability of adequate infrastructure facilities to support each learning activity. By reason of providing good learning facilities to students, the school freely requests monthly payments to parents of students. Whereas we know that, the contribution of infrastructure in education is only $10 \%$, while $90 \%$ of educational success is influenced by the quality of the teacher, the teaching methods provided, and the sources of knowledge used [2]. Based on this, Lendo Novo gave an idea to create a school with a high-quality education quality but could be reached by the general public by establishing alternative schools namely 'Sekolah Alam'.

'Sekolah Alam' is one of the alternative education by utilizing the environment around students as part of the learning process [3]. SAI is the first 'Sekolah Alam' in Indonesia which was established in 1998 and is addressed at Jalan Pembangunan, Cipedak, South of Jakarta [4]. The initial school consisted of only 8 students with 5 students at the playgroup level and 3 students at the elementary school level, now has 305 students at the elementary school level. The concept of education in SAI is based on the Qur'an and hadith which explains that human goals were created, one of which was to become a caliph on the earth. Based on this, the SAI prioritizes education on three material points, namely; 1) akhlakul karimah (attitude to life), 2) training in leadership (leadership), and 3) philosophy of science (logic thinking).

In the National Education System Law of Indonesia, it is explained that in order to meet educational needs, people can take informal and non-formal education pathways without having to take formal education in schools but still in the rules of national education standards. With the existence of the law, those who do not study in formal schools can still get a diploma through an equality test. Therefore, efforts to standardize quality and guarantee that any education provider including alternative 
education such as natural schools should be the focus of attention in an effort to maintain and improve the quality of education nationally. Improvement and development of education administering systems can be done by continuously evaluating the feasibility and performance of schools. This is done to find out the strengths and weaknesses that exist so that efforts can be made to improve them. Based on this, the researchers here will conduct an evaluation of learning in one of the 'Sekolah Alam' namely SAI by comparing the learning activities carried out in the SAI and the existing national education system.

\section{Literature Review}

\subsection{Program Evaluation}

Evaluation is a systematic and objective assessment process carried out on activities, projects, programs, strategies, policies, topics, themes, sectors, regions or operational institutions [5]. As an important part of the policy development process, evaluation provides an accountable and accurate assessment of the relevance, efficiency, effectiveness, impact, and sustainability of the intervention of a program. Evaluation is basically used to answer various questions about the program being evaluated, for example; whether stakeholders have done the right thing or is there a better way to achieve maximum results from a program. Evaluation should, therefore, provide an assessment of what has worked and why, highlight the desired results or accidental results, provide a strategic lesson to guide decision makers and inform any information obtained to stakeholders. Evaluation is a retrospective assessment of each component of the program, starting from planning, the process of output (output) that plays a role in the future in practical situations. Evaluation is preceded by an assessment, while the assessment is preceded by measurement. In evaluating there are seven elements that must be done, namely; (1) determination of the focus to be evaluated, (2) preparation of evaluation designs, (3) information gathering, (4) analysis and interpretation of information, (5) report making, (6) evaluation management, and (7) evaluation for evaluation [6]. Whereas program evaluation is a tool to demonstrate the value of a program's accountability to various stakeholders such as sponsorships, policymakers, states, and local bodies that implement programs and community leaders [7]. Stufflebeam also stated that program evaluation is a study designed and carried out to help several audiences in determining the value and benefits of an object [8]. Program evaluation is intended to try to identify the source of the variance of a program, both internal and external variances to determine whether the variance is desirable or undesirable.

Based on some of these concepts, it can be concluded that program evaluation is a systematic and objective assessment of an activity, project, strategy, policy, topic, theme, sector, operation or institution that is carried out. As an important part of the policy development process, program evaluation provides a timely assessment of the relevance, efficiency, effectiveness, impact, and sustainability of a program. In addition, program evaluations also focus on desired and unwanted results and provide strategic lessons to guide decision-makers and provide information to stakeholders. In the end, the program evaluation should be able to increase the relevance of the program with the achievement of results, optimize the use of resources, provide client satisfaction and maximize the impact of activities both when planning is systematically arranged to the process carried out and expected results.

\subsection{Responsive Evaluation Model}

Responsive evaluation is an approach to measuring the effectiveness of educational programs developed by Robert E. Stake [9]. Robert Stake introduced a responsive approach in 1970 to answer deficit problems that exist in traditional evaluation approaches. Stake believes that the traditional approach does not focus on the needs for whom the evaluation is carried out. Stake sees a responsive approach as a transaction evaluation model because it concentrates on the education process, not the result of education. Responsive models adopt a naturalistic paradigm that emphasizes the importance of understanding someone and the program in a real context. This approach can be used to evaluate educational programs and social service programs by comparing program activities, program uniqueness, and diversity that exist in the social environment of the community. The most important thing in this responsive evaluation is the response of the people involved in a particular program to the problems faced in the process of implementing the program. Therefore, in using this approach, an evaluator must be aware that there are many perspectives in each individual or group on the reality of the truth that exists [10].

The advantages of Stake responsive evaluation are; 1) allows questions that arise during the evaluation process to take place apart from the questions that have been formulated before, 2) allow evaluators to gain a quick understanding of the program being evaluated and can determine the most crucial problems for stakeholders, 3) are flexible, the information obtained describes a program in a way that is easy and accessible to the audience, 4) it is feedback, providing an opportunity for the audience to be able to interact directly with the evaluator regarding the problems and concerns they face. The disadvantages of the Stake responsive evaluation model are; 1) the issue of time commitment, the more problems faced, the longer the time needed, 2) the high level of interaction between stakeholders, the role of the evaluator being ambiguous between a resource person or as a researcher, 3) because it is flexible, this evaluation is difficult to maintain focus on evaluation and can cause failure to answer specific questions.

In general, important steps that evaluators must take in using responsive evaluations include; 1) conduct evaluation preparation, 2) involve all stakeholders, 3) identify the objectives of the evaluation, 4) arrange the right questions, 5) design the stages of evaluation carried out, 6) sort and implement evaluation instruments, 7) collect data, 8) analyze data, 9) provide data on the results of stakeholder evaluation. Criteria in responsive evaluation come from problems faced by program stakeholders. Responsively the evaluation stakeholders must actively participate in the evaluation process, starting from the formulation of questions, selection of participants and interpretation of findings. In a methodological sense, design gradually emerged in discussions between evaluators and stakeholders. 


\subsection{Countenance Evaluation Model}

Stake's countenance evaluation model focuses on evaluating processes rather than actual educational goals. This evaluation model seeks to find information about the background of the program so that it can develop existing program objectives. Things that are evaluated in educational programs, for example, are program plans that consist of curriculum, program planning, teaching, and education subjects themselves [11]. This evaluation model considers the complex educational environment and various problems faced by stakeholders. This evaluation model places the importance of the results of observations, descriptions, and evaluations of the program through various data sources and data analysis between stakeholders and evaluators. The countenance evaluation model is also used to find information about the suitability of program objectives, processes that are influenced by internal and external factors in program implementation, and program results.

The stages in the countenance evaluation model consist of a) input (antecedents), transactions, and results (output), b) observation as the process of recording objective conditions, c) analysis, as standard actualization with objective intensity or condition, and d) decisions with follow-up or recommendations. Countenance evaluation has advantages with two basic main components, namely description, and decision. The evaluator can also analyze information based on the description matrix by looking at the suitability between the objectives and observations, seeing the dependencies (contingencies) of the results on transactions and antecedents, or the results of transactions on antecedents. The decision will be made by applying the standard to the data descriptively [12].

The antecedent is a condition that exists before learning takes place related to results, while a transaction is a process of the learning experience. There are two ways that can be used to process descriptive evaluation data on educational programs, namely finding contingency between the antecedents, transactions, and outcomes and congruence between expected goals and observed conditions. It should be noted whether the implementation plan of learning is in accordance with the implementation of classroom learning or irregularities occur. Curriculum data is SAI $d$ to be congruence if the expected goals are actually fulfilled. In one data matrix, evaluators can compare cells that contain goals and observations, to record gaps and explain a congruence with that line. Relationships or contingencies between variables need attention. In evaluating educational programs that look for possible relationships to improve educational programs, the evaluator's task is dependent on the results of identifying conditions that occur in antecedents and conditions that occur in the transaction. Observation of contingencies depends on empirical evidence. Analysis of contingencies includes logical analysis and empirical analysis. Logical analysis is done to give consideration to the relationship between antecedents, transactions, and the results of the destination boxes. The evaluator must be able to determine whether the antecedent that has been stated in the development of the learning program will be achieved with the proposed transaction plan or actually there is another model of transaction that is more effective. Similarly, the relationship between transactions and expected results. The second analysis is empirical analysis.
The working basis is the same as logical analysis but the data used is empirical data.

\subsection{Learning Program of SAI.}

'Sekolah Alam' is one form of alternative education in Indonesia by involving nature as the main means of learning for its students. 'Sekolah Alam' seeks to invite students to interact directly with living things in the universe. In the concept of natural school education, there are 3 functions, namely: nature as a learning space, nature as a medium and teaching material, nature as an object of learning [13]. Efforts to involve the surrounding environment as a means of learning are part of contextual learning. The contextual approach is a learning concept that helps educators associate the material they teach with real-world situations of students. This is done by involving the main components of effective learning, constructivism, questioning, inquiry, learning community, modeling, reflection, and authentic assessment.

SAI has a vision center of excellence, education of leaders with character. While its mission is to build a generation of independent and responsible future leaders through a series of learning about life (real-life experience) by involving certain communities. SAI has core values in deepening the value of faith and Ihsan, including; integrity, maturing, accountability, nature savvy, influential, humble, 'socio-preneurial', agile, and novels. The concept of education in the SAI is based on the Qur'an and Hadith which explains that human goals are created, one of which is to become a caliph on the earth. Based on this, the SAI prioritizes education in three material subjects, namely; 1) akhlakul-karimah (attitude to life), 2) training in leadership (leadership), and 3) philosophy of science (logic thinking). The building contained in the SAI consists of classrooms made of wood material. Facilities owned by the SAI consist of; mosques, classrooms, libraries, outbound spaces, sports fields, gardens, and farms. The class building is in the form of a stage with floors made of wooden boards and arranged according to the sex of the students. Saung is surrounded by a fence to protect the learning activities of SAI students. All footwear is stored under a Saung so that teachers and students are on the floor with makeshift learning equipment such as folding tables that are easily conditioned according to their use. In addition to the teaching and learning process, the Alam Indonesia School also has several routine activities each year. Such routine activities include; OTFA (out tracking fun adventure), memorize the Qur'an (familiarize yourself with reading the Qur'an), Market Day in shaping the young entrepreneurial spirit of its students, Indonesia Culture who joined the parenting class introducing some famous figures in Indonesia, Language Fair (socio-drama), Day Camp (aims to train independence, courage, leadership and student cooperation), and outing class.

SAI comes with a new paradigm of free education. The students are given freedom of expression, experimenting and exploring without dividing the walls of various rules that curb students' curiosity. Schools become playgrounds and learning. The students are freed to be themselves, develop the potential to grow into independent, character, noble, knowledgeable and ready to become leaders in accordance with the nature of human creation to become 
the caliph of the Prophet. The students are freed from pursuing grades and rankings but are encouraged to foster a scientific tradition, even for graduation requirements, at the 6th-grade level elementary students have to be able to complete simple research with the Younger Explorer program. Student achievement in school is not seen by comparison with other students, but from efforts to maximize self-potential and become better. Every child is unique, blessed with the advantages and disadvantages of each. Learning to find fun activities, not burdensome. Learning becomes a necessity, not a necessity. Schools don't become boring prisons. This school is a community-based school, which is organized by a group of people who have the same desire to create quality schools that do not have to be expensive by involving the community and utilizing existing resources in order to build civilization. By holding the basic principle that education is the right and obligation of parents, and schools should not take over it, then SAI is present to become a partnership of parents in children's education. Organizing education at the SAI is a synergy between teachers, school organizers, parents and all components of the community. All are fully involved and active and work together in the learning process. All intervene and care about school development because schools do not belong to a particular foundation or person, but SAI belongs to all members of the community. More than that, in SAI not only students study, teachers learn from students and parents, parents learn from teachers and students.

\section{Research Method}

Based on the two evaluation models previously explained, each model has its own advantages and disadvantages. The advantages of responsive evaluation models include; 1) evaluation is more directed towards the process of program activities compared to the objectives of the program, 2) involving all stakeholders to obtain information, 3 ) information obtained directly in the form of advantages and disadvantages of perceived programs, 4) is participatory so as to increase local control. While countenance evaluation has advantages with two basic main components, namely description, and decision. The evaluator can also analyze information based on the description matrix by looking at the suitability between the objectives and observations, seeing the dependencies (contingencies) of the results on transactions and antecedents, or the results of transactions on antecedents. The decision will be made by applying the standard to the data descriptively. Based on these two things, then the elementary school evaluation study of Sekolah Alam Indonesia will use evaluation of the Stake countenance model. The description of the evaluation to be carried out is as follows;

\section{a. Antecedents Stage}

According to Stake, the antecedent is a condition of requirements before the teaching and learning process takes place and affects the results expected to be achieved [14]. In a study conducted by Siswanto, it was stated that the stages of antecedents in Stake's countenance evaluation sought to evaluate the factors supporting the implementation of learning, including; facilities and infrastructure, interests, as well as student education background to accounting learning [15]. Whereas in the journal written by Astin Lukum, it was stated that the stages of antecedents in Stake countenance evaluation were measured based on the learning implementation planning standard (lesson plan) [16]. The same thing was done by I Putu Mas Dewantara, who stated that the antecedents at Stake's countenance evaluation tried to see how well the learning plan had been carried out by the lecturer before teaching Indonesian based on established standards [17]. Based on several journal analyzes, it can be concluded that the antecedents in the Stake countenance evaluation phase are trying to evaluate the planning of a program. Because Stake's countenance evaluation is very suitable in evaluating learning programs, planning can be seen from the curriculum used, the learning plan developed, and other supporters prepared in achieving the learning objectives. For this reason, in evaluating the SAI learning program, the stages of the antecedents to be evaluated are; school curriculum, school facilities and infrastructure, school human resources, and school funding standards.

\section{b. Transactions Stage}

Stake argues that what is meant by the transaction is an interactive activity that occurs, both interactions between students and teachers, students with students, writers with readers, parents with counselors [18]. The interaction activity is part of the learning process which is expected to run according to the learning objectives. In a study conducted by Harto Sundoyo, it was stated that the transaction stage in evaluating Stake countenance was done by evaluating the program's implementation in a dual system education program based on; 1) time of implementation, 2) qualifications of PSG supervisors, 3) DU/ DI instructor qualifications, 4) DU / DI assessment criteria, and 5) DU/DI instructor involvement [19]. Whereas Siswanto and I Putu Mas Dewantara evaluated the learning program at the transaction stage through a comparison of the implementation of the learning process with the previously planned learning program plan [20]. Based on the analysis of several journals, the evaluation of the SAI learning program on the transaction stage that will be evaluated is the implementation of learning and assessment learning.

\section{c. Outcomes Stage}

Stake argues that what is meant by outcomes is something that is expected from the interactions that occur. Outcomes are a result of ongoing educational processes; both short and long term, cognitive and conative, personal and group. Whereas according to Stufflebeam, outcomes evaluation which is defined as the evaluation of results is an evaluation that aims to measure, interpret, and assess the achievement of the program [21]. Feedback on important achievements or achievements during program implementation and as a conclusion. While in the journal written by Amalia Puspayanti it is stated that, outcomes evaluation can be seen from the results obtained in the training which includes knowledge, skills, attitudes, and values or easily interpreted by the learning outcomes of the training participants [22]. Based on the analysis of several journals, then in the evaluation study of the Alam Alam Indonesia learning program at the outcomes stages to be evaluated were school achievement, school graduation, and the level of satisfaction of students' parents. 


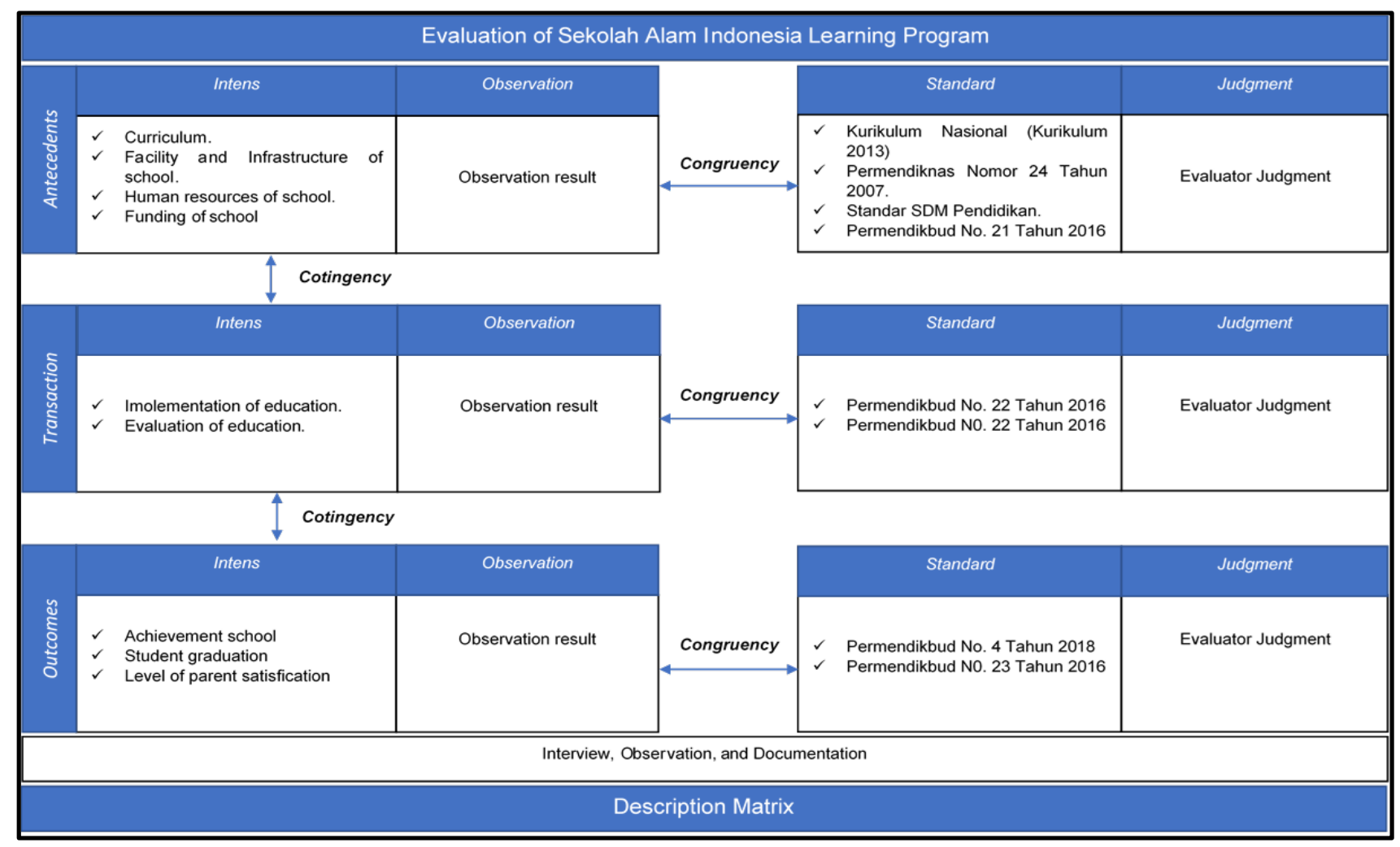

Figure 1. Design of Evaluation Research

\section{Discussion}

\subsection{Congruency}

\subsubsection{Antecedents Stage}

Interviews were conducted with the principal and several teachers in the SAI in finding information about the components of the antecedents at the Stake countenance stage. The results of the interview to the headmaster showed that the SAI had developed a school curriculum outside the applicable national curriculum. The school curriculum is also developed based on the potential of the area around the SAI environment. But the school still refers to the applicable national curriculum, so that education in the "Sekolah Alam Indonesia" uses two curricula, namely; national curriculum and development curriculum. The policy of developing the SAI curriculum is considered to be in accordance with the national curriculum because teachers have used school autonomy in developing the curriculum in accordance with the potential of the area in learning planning. So as to encourage students to take active learning. The development of the SAI curriculum was carried out with the aim of building a generation of noble character through wisdom and exemplary methods, building generations that have the logic of scientific thinking through active learning methods, and building generations that have leadership skills through dynamic group methods and outbound activities. SAI apply active learning but still prioritizes the scientific approach.

Teachers at SAI also explained that at the beginning of the learning year they also developed annual, semester and daily programs. The annual and semester programs called syllabus by teachers contain school identity including the name of the education unit and class. The SAI syllabus also contains core competencies which are categorical descriptions of competencies in aspects of attitudes, knowledge, and skills that students must learn for a school, class and subject level. In addition, the SAI syllabus also describes basic competencies which are specific abilities that include attitudes, knowledge, and skills related to content or subjects. While their daily programs are called weekly plans. For extracurricular programs carried out outside of study hours in the form of Tahfizh Qur'an, Taekwondo, Archery, Drawing and Dancing activities. In addition, the SAI also organizes inclusive education services for children with special needs. According to one SAI teacher, learning planning in schools is carried out at the school level and at the classroom level before new teachings begin. At the school level, the Principal and curriculum development team develop curriculum and learning programs that emphasize three aspects, namely moral development, leadership and thinking skills. The Learning Program arranged at the school level is called the "School Theme". The theme of the School is then revealed to be a class program or called "Class Theme" which is arranged through work meetings for two weeks before the new school year begins with all class teachers, which are contained in one year learning planning which is then broken down into lesson plan, and daily learning plans that produce work-based problem solving for each learning theme (project plan).

The interview results on the aspects of facilities and infrastructures show the suitability between SAI facilities and infrastructures in supporting learning activities with educational facilities and infrastructure standards stipulated in Permendikbud Number 21 of 2016. Land used by SAI avoids potential hazards that threaten life's health and safety and has access to the rescue in an emergency, as 
well as various kinds of pollution. Land in accordance with the allotment of location stipulated in the Regional Regulations concerning Regency / City Regional Spatial Planning or other plans that are more detailed and binding, and obtain land use permits from the Regional Government and have utilization permits from holders of land rights in accordance with statutory regulations - invitations valid for a minimum period of 20 years. SAI has classrooms, library rooms, science laboratories called aquaponics gardens, school leadership rooms, teacher rooms, UKS rooms, places of worship, bathrooms/toilets, toilets, playgrounds and other equipment such as sports equipment, loudspeakers, flagpoles, shelves, cabinets, and so on.

The results of interviews with human resource management show the conformity between HR management at Sekolah Alam Indonesia and the applicable HR management standards of education. SAI has 15 study groups with 305 students this year. The ratio of the number of teachers in the SAI has met the number of existing study groups. School principals and SAI teachers have a minimum D4 / S1 education qualification with teaching experience and special administrative affairs executives. According to the principal, SAI teachers must have the required criteria, including; 1) has the motive of an educator who loves children, 2) has a developing mindset, 3) has high field experience or analytical skills, and 4) does not smoke and use drugs. While the criteria that must be met by students is the age that is in accordance with the psychology of child development. They tend not to accept students who are too young from their learning age groups. SAI teachers are given benefits according to their performance. Increasing the competence of SAI teachers is carried out through training activities, discussion group forums, and seminars. Scholarships are also given to students and teachers who excel even though there are not too many.

While the results of interviews with school principals regarding school financing management are in accordance with the applicable education financing standards. SAI has a list of students with a clear economic background. Operational and non-operational costs are delivered to all parents of students at the beginning of the new school year. More operational costs come from parents (class fundraising) for outing class activities. School operational assistance is also provided and managed properly by the SAI. SAI also implements cross-subsidies to help disadvantaged students. The education budget is planned based on realistic needs in accordance with the results of the context analysis to improve student achievement in SAI. The report on the use of existing education funds can be accessed by stakeholders.

Table 1. Antecendent Level Observation Result

\begin{tabular}{|c|c|c|c|c|c|}
\hline No & Aspect & Score & Avg & $\mathbf{\%}$ & Category \\
\hline 1 & Curriculum & 100 & 0.61 & 61 & quite appropriate \\
\hline 2 & $\begin{array}{c}\text { Facility and } \\
\text { Infrastructure }\end{array}$ & 130 & 0.81 & 81 & in appropriate \\
\hline 3 & Human resource & 65 & 0.87 & 87 & very appropriate \\
\hline 4 & Funding school & 45 & 0.90 & 90 & very appropriate \\
\hline \multicolumn{2}{|c|}{ Overall Evaluation } & 340 & 0.76 & 76 & in appropriate \\
\hline
\end{tabular}

\subsubsection{Transactions Stage}

The results of interviews with SAI teachers showed that the time allocation in the learning process for each class and each subject of learning material varied with the time variance between 45 minutes to 60 minutes. The main learning resources used in the Alam Alam Indonesia School come from the Qur'an and Hadith, history, everyday phenomena or events, books, the internet, and documentaries. Teachers also tend to develop simple worksheets to support learning activities. All activities that will be carried out have been designed beforehand so that when the learning process is carried out the teacher only needs to follow the learning procedures he has made. The implementation of learning is done in the classroom and outside the classroom.

Conditioning at the beginning of the learning process is carried out before starting learning activities such as arranging student seats that are adjusted to the activities to be carried out. Learning is done through a preliminary process such as conveying the content of the material to be taught, the activity of prayer and giving motivation to all students. The core activities are carried out through exploration, elaboration, and confirmation. The exploration phase is done through question and answer between students and teachers about the material to be taught. The elaboration activity is carried out by teachers to familiarize students with diverse reading and writing through assignments or discussions to bring up new ideas both verbally and in writing, facilitating students to present the results of individual and group work. The confirmation phase is carried out by the teacher to provide feedback and reflection on the learning experience that has just been experienced by students. After that, the teacher ends the learning activities with closing activities such as delivering the next learning material to be carried out and giving additional assignments to students.

Table 2. Transaction Level Observation Result

\begin{tabular}{|c|c|c|c|c|c|}
\hline No & Aspect & Score & Avg & $\%$ & Category \\
\hline 1 & Learning plan & 62 & 0.89 & 89 & very appropriate \\
\hline 2 & $\begin{array}{l}\text { Implementation of } \\
\text { learning plan }\end{array}$ & 71 & 0.95 & 95 & very appropriate \\
\hline 3 & $\begin{array}{c}\text { Evaluation of } \\
\text { learning }\end{array}$ & 30 & 1 & 100 & very appropriate \\
\hline \multicolumn{2}{|c|}{ Overall Evaluation } & 163 & 0.93 & 93 & very appropriate \\
\hline
\end{tabular}

\subsubsection{Outcomes Stage}

The results of interviews regarding the achievements obtained by SAI students indicate that the quality of elementary school students is still able to compete with formal schools or other alternatives both academically and non-academically. The SAI non-academic achievements that have been achieved are; Second place winner (two) in the Jakarta Championship Pencak Silat championship, 1st place (one) archery competition organized by DSR institutions, and Indonesian Champion II archery at the national level group category. Sekolah Alam Indonesia once competed for 4 (four) gold medals, 12 (twelve) silver medals, 29 (twenty nine) bronze medals, and 4 (four) merits at the Asia International Mathematical Olympiad held in Hong Kong and managed to bring 2 medals bronze for Indonesia. This shows that the quality of learning at SAI is not inferior to other schools.

The outcomes evaluation also looked at how the graduation rates of the SAI students took part in the elementary school national exam or better known as 
USBN. The average score of graduating SAI students in 2018 has decreased compared to the previous year and is included in the sufficient category. For Indonesian Language, Mathematics and Science subjects, the average score obtained by SAI students in a row is $65.58 ; 57,60$; and 67.75. Although the value of USBN is not a standard for student graduation, it is used as the main requirement in the acceptance of new students (PPDB) through the achievement path. This certainly has an impact on parents and students who want to go on to excellent formal schools but can be less competitive with the values obtained by other school students. Seeing these conditions, researchers tried to interview several parents of students. The results of the interview show the anxiety of parents of students, especially parents of class V students. Parent tend to be afraid of their students do not get maximum grades, so they cannot continue their education to a superior school. Some of them called private tutors at home to teach their children on USBN. But not a few parents of students who are not too concerned about the condition. The main thing according to them is the values of life taught in SAI. The values of independence, leadership, responsibility, and others taught by the SAI are more needed in preparing their children in the current era of competition compared to the values obtained by students.

Outcomes evaluation was also conducted by finding out the level of satisfaction of students' parents towards SAI. The results of interviews with several parents stated that they were satisfied with the services provided by the SAI in the learning process. Class teachers who accompany their children are perceived as communicative about the development of their students in school, especially teachers who are more senior. If there are difficulties experienced by students, the teacher informs the parents openly. The quality of human resources involved in the learning process at SAI is considered quite good by the parents of students. Teachers are considered to have more closeness than teachers in other schools that have more than 30 students. The facilities and infrastructures in SAI are also considered to be quite conducive and fulfill the prerequisites in carrying out daily learning activities. Some of them also support the school to be able to improve existing facilities for the education of their children both in terms of costs and procurement.

Table 3. Satisfication Level Observation Result

\begin{tabular}{|c|l|c|c|c|}
\hline No & Aspect & Avg & $\mathbf{\%}$ & Category \\
\hline 1 & Facility and Infrastructure & 0.84 & 84 & satisfied \\
\hline 2 & Budget of education & 0.93 & 93 & very satiefied \\
\hline 3 & Human resource & 0.75 & 75 & satisfied \\
\hline 4 & Implementation of education & 0.83 & 83 & satisfied \\
\hline 5 & Achievement and graduate & 0.80 & 80 & satisfied \\
\hline \multicolumn{2}{|l|}{ Overall Evaluation } & 0.83 & 83 & satisfied \\
\hline
\end{tabular}

\subsection{Contingency}

Overall, the evaluation of the learning program at the Alam Alam Indonesia School is in accordance with the standards for implementing elementary school learning in force. As an institution that develops from the values of glory, the School of Nature Indonesia has the mission of education to develop a generation of leaders who have noble character through real life experience in a community, namely school. The basic concept of education in the Sekolah Alam Indonesia is contained in the principles of the school of life where the School of Nature Indonesia believes that a learning experience is the best teacher for students. Thus learning is done in order to provide as much experience as possible to students through games, projects, cooperation, service and business. HR who are involved in the learning process at the Alam Alam Indonesia School have developed the school curriculum independently with principles; all children are born unique and have equal opportunities to be great, all learning has an impact on goodness, teaching and learning activities refer to conditions in real life with school ideals in general, the learning process is not an activity to fill the child's brain with various knowledge but based on experience with active learning and integrated thematic approach. To realize this, the school has provided facilities and infrastructure to support the activities of student learning activities in schools, quality human resources are indicated by a minimum of teacher education is a graduate of education and must meet the criteria determined by the school, accountable and transparent funding management, and planning activities which will be carried out both annually and weekly.

The learning process at Sekolah Alam Indonesia does not only emphasize cognitive aspects, but also emphasizes the learning experience of students. The learning experience was formed through learning activities that were not only conducted in the classroom, but also carried out by utilizing the environment around the students. Early on students are directed to become inventors or researchers. Various media are developed and used by teachers when the learning process takes place. The main source in the learning process at the Alam Alam Indonesia School is the Qur'an and Hadiths that bring students closer to the existence and power of God towards what is in the environment around students. Some book sources are also used by teachers in enriching students' knowledge and experience. The assessment conducted by the Sekolah Alam Indonesia teacher is not only a written test assessment. Teachers of the Alam Indonesia School also developed assessment instruments to measure the achievement of the learning done. Information obtained from these assessments is collected in the form of portfolio assessments.

Development of a curriculum that is tailored to the conditions of the student learning environment, facilities and infrastructure provided by the school, transparent, effective and accountable financing management, quality human resources directly involved in students' daily school activities, and the implementation of learning that emphasizes the three aspects, cognitive, affective and psychomotor, making students in the School of Nature Indonesia able to develop well. This is indicated by the achievements obtained by Indonesian Nature School students and students both academically and non-academically. The average results of the USBN of the students of the Alam Indonesia School are still in a sufficient category even though they must be improved in order to provide more opportunities for alumni who want to continue their 
education in superior formal schools. The level of parental satisfaction of students is also in the satisfied category, which shows that the average parents of students who send their children to the Alam Indonesia School strongly believe in the education services provided by the school. They also continue to support all forms of school programs that are able to develop the quality of education in the School of Nature Indonesia to be even better.

\section{Conclusion}

The evaluation at the stage of antecedents obtained a percentage of $76 \%$, which means that education planning in SAI is in the category in accordance with applicable education planning standards. The input of evaluators on SAI is to develop RPP with minimum components that must be met in Education and Culture Minister Number 22 of 2016. Schools need to pay attention to the land used whether they have avoided potential hazards that threaten life's health and safety, and have access to rescue in an emergency or not. If there is no need for an effort to improve in the future because school land is a public facility that is used by many people to carry out various activities in it, especially children. Schools also need to pay attention to certain regions/zones whether they have the ability to be able to withstand earthquakes and natural forces and be equipped with passive protection systems and/or active protection in preventing and overcoming fire and lightning hazards because there are many classes of activities that occur within the school building. inclusion in it. The use of IT in providing information regarding school administration needs to be done and can be informed through the website that is available on SAI.

The evaluation of the learning program at SAI at the transactions stage received a percentage of $93 \%$, which means that the process of implementing learning in SAI was very much in accordance with the standards of the learning process stipulated in the Minister of Education and Culture Regulation No. 22 of 2016. The input to school is the time 45 minutes of face to face can be used by the teacher to prepare students to face USBN material, especially at the elementary school level grades 4,5 and 6 by enriching students who have achieved basic competencies in the classroom. So that students are also ready to implement USBN in the future. IT users in the learning process also need to be done in order to keep up with the times and emphasize positive values in utilizing IT.

Evaluation of SAI learning at the stages of outcomes must still be of concern to the school, especially in preparation for USBN. A research program for 6th-grade students, as the final assignment for graduation requirements, is a breakthrough program that is very good for students. In addition to measuring the achievement process of children's thinking skills, in the long run, this will also encourage the birth of new discoveries that are useful for real life so that this program needs to be continuously optimized by guiding and mentoring in its implementation and the existence of good documentation and publication of results.

\section{References}

[1] UNDP (United Nations Development Programme), Human Development Indicators and Indices: 2018 Statistical Update (New York: United Nations Development Programme) 2018.

[2] Yayasan Perspektif Baru, Sekolah Alam, 2009 http://www.perspektifbaru.com/wawancara/695.

[3] Suhendi, Belajar Bersama Alam, (Bogor: SoU Publisher), 2008.

[4] Rohinah, "Sekolah Alam, Paradigma Baru Pendidikan Islam Humanis", Jurnal Nadwa, Semarang, Vol.8 (2), 2014.

[5] Barrett, W. Gordon. Educational Evaluation: Two Theoretical Models in a Corporate Based Application, A Thesis Submitted in Partial Fulfilment of The Requirements for the Degree of Master of Arts in The Faculty of Graduate Studies (Department of Language Education), 1999.

[6] Frye, Ann W. \& Paul A. Hemmer, "Program Evaluation Model and Related Theories", Journal Medical Teacher, Vol. 34 (62), 2012.

[7] Fitzpatrick, J.L., J.R. Sanders, \& Worthen, Program Evaluation: Alternative Approaches and Practical Guidelines (Boston: Pearson), 2004.

[8] M, Sara Steele. Contemporary Approaches to Program Evaluation, Implication for Evaluating Program for Disadvantage Adults (Washington DC: Capitol Publication Inc), 1977.

[9] Curran, Vernon, Jeanette Christopher, Francine Lemire, Alice Collins, \& Brendan Barrett, "Application of a Responsive Evaluation Approach in Medical Education", Medical Education Journal, Vol. 37 (3), 2003.

[10] A. Abma, Tineke. "Responsive Evaluation: ts Meaning and Special Contribution to Health Promotion", Journal Evaluation and Program Planning Vol. 28, 2005.

[11] Dewantara, I Putu Mas, "Stake Evaluation Model (Countenance Model) in Learning Process Bahasa Indonesia at Ganesha University of Educational", ResearchGate, Vol.1 (1), 2017.

[12] Lukum, Astin. "Evaluasi Program Pembelajaran IPA SMP Menggunakan Model Countenance Stake", Jurnal Penelitian dan Evaluasi Pendidikan, Vol.19 (1), 2015.

[13] Siswanto, "Penerapan Model Evaluasi Stake (Countenance) untuk Mengevaluasi Pembelajaran Dasar-Dasar Akuntas", Jurnal Pendidikan Akutansi, Vol.8 (1), 2009.

[14] Stake, Robert. International Handbook of Educational Evaluation (Springer Netherlands: Kluwer International Handbooks of Education), 2003.

[15] Stake, Robert. Standards-Based \& Responsive Evaluation (California: Sage Publications), 2004.

[16] Stake, Robert. The Countenance of Educational Evaluation (Berkeley.CA McCutchen), 1977.

[17] Stufflebeam, Daniel L., dkk, Evaluation Models, Viewpoints on Educational and Human Service Evaluation (USA: Kluwer Academic Publishers), 2002.

[18] Sundoyo, Harto, Totok Aumaryanto, dan Dwijanto, "Evaluasi Program Pendidikan Sistem Ganda Berdasarkan Stake Countenance Model" Innovative Journal of Curriculum and Educational Technology. Vol.1 (2), 2012.

[19] Atmaja, RM. Teguh Eko, Cut Zahri Harun, Sakdiah Ibrahim. "Analisis Penetapan Standar Pembiayaan Sekolah" Jurnal Administrasi Pendidikan Pascasarjana Universitas Syiah Kuala, Vol. 4 (1), 2016.

[20] Daulay, Musnar Indra. "Kepuasan Orangtua Terhadap Layanan Pendidikan Lembaga PAUD di TK Qurrota Ayun Pekanbaru" Journal of Islamic Early Childhood Education, Vol.1 (1), 2018.

[21] Puspayanti, Amelia. "Evaluasi Pembelajaran Diklat Menggunakan Model Countenance Stake", Jurnal Diklat Teknis, Vol.6 (1), 2018.

[22] Stufflebeam, Daniel. L. and Anthony J. Shinkfield. Evaluation Theory, Model and Application (San Fransisko: Jossey-Bass), 2007. 